\title{
ANALYSIS OF NOTARY HONORARY COUNCIL CONSENT AS GROUNDS OF IMPUNITY (STRAFUITSLAUTINGSGRONDEN) AGAINST REVELATION OF SECRETS
}

\author{
Gaza Carumna I; Anggita Mustika Dewi \\ Faculty of Law, Universitas Gadjah Mada \\ Email: gazacarumna@yahoo.com; anggitamd@gmail.com
}

\begin{abstract}
Article 66 paragraph (1) Law Number 2 of 2014 essentially regulates the consent of the Notary Honorary Council in the criminal justice process. The provisions in the a quo article have been still being applied and become a positive law in Indonesia. One of the criminal justice process in the notarial field relates to the criminal Law of revelation of secrets as regulated in Article number 322 paragraph (1) of the Criminal Code. The consent given by the Notary Honorary Council as outlined above can certainly be viewed in the context of criminal law. The research is a normative legal research using secondary data of both primary legal materials and secondary legal materials. The data collecting technique used is documentary study with written materials as the data collection tool to be analyzed qualitatively using content analysis. The research result showed that in the context of criminal law, basically a notary who provides a copy of the deed and/or documents attached to the minuta deed or notarial protocol in the notarial archives for the purpose of the investigator, the public prosecutor or the judge has committed a criminal Law of revelation of secrets as stipulated in Article number 322 paragraph (1) of the Criminal Code. However, the notary is not necessarily criminally liable considering the consent of the Notary Honorary Council as the grounds of impunity.
\end{abstract}

Keywords : Notary Honorary Council consent, grounds of impunity, criminal Law of revelation of secrets.

\section{A. INTRODUCTION}

In the notarial field, the current legal regulation in Indonesia is Law Number 30 of 2004 on Notary Public Official jo. Law Number 2 of 2014 on Amendment to Law Number 30 of 2004 on Notary Public Official. Law Number 2 of 2014 has amended some of the articles in the Law Number 30 of 2004 because they are no longer appropriate for the development of law and the needs of the society (see General Elucidation of the Law Number 2 of 2014). Based on the provisions of Article 1 sub- 
article 1 of the Law Number 2 of 2014, "a notary is a public official authorized to make an authentic deed and has other powers referred to this Law or under any other Law". The meaning of a notarial deed is "an authentic deed made by or before a notary according to the form and procedure specified in this Law" (see Article 1 sub-article 7 of the Law Number 2 of 2014).

Furthermore, a notarial deed is categorized as an authentic deed as it complies with the provision of Article 1868 of the Civil Code stating "an authentic deed is a deed which, in the form prescribed by the Law, is made by or in the presence of the public officials in the place where the deed is made” (R. Subekti and R. Tjitrosudibio, 2014:475). Meaning that:

1. A notarial deed must comply with the provisions of a deed as provided in Article 38 of the Law Number 2 of 2014, so as to comply with the clause of "a deed in the form prescribed by the Law";

2. A Notarial Deed consists of two types, namely a deed made by (door) a notary called relaas deed (official record deed) and a deed made before (ten overstaan) a notary (Habib Adjie, 2013:57) called partij deed (deed of the parties). Relaas deed (official record deed) is a letter of evidence made by a notary on what he or she sees, knows or notices, and the occurrence of the Law is witnessed directly (Salim H.S., 2016:90), while partij deed (deed of the parties) is a deed made by a notary based on the will of the parties or constituents, or the constituents who come to the notary to make a deed. In an partij deed, a notary is limited to writing down the will of the parties (Mulyoto, 2010:46). Based on the explanation, the clause "made by or before the public officials who has the authority over it" have been fulfilled; and

3. A notarial deed must be made within the territory of his office covering the whole of the province of his place of residence (see Article 18 paragraph (2) of the Law Number 30 of 2004), so as to satisfy the clause "in the place where the deed is made". 
Associated with the notarial deed, the notary has the obligation to make a deed in the form of minuta deed (original of the deed) and keep it as part of notarial protocol (see Article 16 paragraph (1) letter b of the Law Number 2 of 2014). The meaning of minuta deed is "original deed which includes the signatures of the witnesses and notaries which are kept as part of notarial protocol" (see Article 1 sub-article 8 of the Law Number 2 of 2014). While a notarial protocol is defined as "a collection of documents that is the state archives that should be kept and maintained by a notary in accordance with the provisions of legislation" (see Article 1 sub-article 13 of the Law Number 2 of 2014).

In executing notarial procedures in making a notarial deed, the notary may be sued in civil or criminal liabilities. It is stated in the Law Number 30 of 2004 that if the notary is involved in the criminal justice process, the Regional Supervisory Board has an important role in giving a consent as referred to in Article 66 paragraph (1) of Law Number 30 of 2004 which states:

For the purposes of the judicial process, the investigator, the public prosecutor, or the judge with the consent of the Regional Supervisory Board is authorized to:

a. take a copy of minuta deed and/or documents attached to meaning minuta deed or notarial protocol in the notary's archieves; and

$b$. invoke notary to be present in the examination relating to the deed of which he has made or the notarial protocol which is in the notary's archieves.

However, the judicial review of the Constitutional Court regarding the authority of the Regional Supervisory Board in the a quo article is submitted through the Constitutional Court Decision Number 49/PUU$\mathrm{X} / 2012$. The Constitutional Court then declares that the phrase "with the consent of the Regional Supervisory Board" in the a quo article is contradictory to the 1945 Constitution of the Republic of Indonesia and has no binding legal force (see Decision of Constitutional Court Decision Number 49/PUU-X/2012, page 49). 
In the development as previously described, some provisions in the Law Number 30 of 2004 are amended by Law Number 2 of 2014, one of which is by creating a new institution that is the Notary Honorary Council as stipulated in Article 66 so as to read as follows:

(1) For the purposes of the judicial process, the investigator, the public prosecutor, or the judge with the consent of the Notary Honorary Council is authorized to:

a. take a copy of minuta deed and/or documents attached to minuta deed or notarial protocol in the notary archieves; and

b. invoke notary to be present in the examination relating to the deed of which he has made or the notarial protocol which is in the notary archieves.

(2) The taking of the copy of minuta deed or documents as referred to in paragraph (1) letter a, the submission of official report shall be made.

(3) Notary Honorary Council, as referred to in paragraph (1) shall give answer to accept or reject the request for consent within 30 (thirty) working days at the latest from the date of the application document for consent

(4) In the case where the Notary Honorary Council fails to provide an answer within the time period referred to in paragraph (3), the Notary Honorary Council shall be deemed to receive the request for consent.

The provision in Article 66 paragraph (1) Law Number 2 of 2014 has the similarity of substance with the provisions of Article 66 paragraph (1) Law Number 30 of 2004 previously declared contrary to the 1945 Constitution of the Republic of Indonesia and has no binding legal force based on the Constitutional Court Decision Number 49/PUU-X/2012. A judicial review of the Constitutional Court Article 66 Paragraph (1) Law Number 2 of 2014 has Lawually been filed, but the Court through the Constitutional Court Decision Number 72/PUU-XI/2014 states that the request cannot be accepted because the applicant has no legal standing so 
that the principal of the petition of the petitioner has not been considered by the Constitutional Court (see Decision of Constitutional Court Decision Number 72/PUU-XI/2014, page 58). Apart from the consideration of the Constitutional Court Decision Number 49/PUU-X/2012 (see Consideration of Constitutional Court Decision Number 49/PUU-X/2012, page 44-48), the provisions in article a quo is still valid and become the positive law in Indonesia.

One of the criminal justice process of notary is related to the criminal Law of revelation of secrets as stipulated in Article 322 paragraph (1) of the Criminal Code written "any person who with deliberate intent reveals a secret that he by reason of either his present or earlier office or profession is obliged to keep secret shall be punished with a maximum imprisonment of nine months or a maximum fine of six hundred rupiahs" (Moeljatno, 2011:117). The consent given by the Notary Honorary Council as described above may be viewed in the context of criminal law against the criminal Law of revelation of secrets as stipulated in Article 322 paragraph (1) of the Criminal Code.

\section{B. PROBLEM STATEMENT}

Based on the introduction above, the problem formulation in this study is "how is the Notary Honorary Council consent viewed from the context of criminal law against revelation of secrets as stipulated in Article 322 paragraph (1) of the Criminal Code?".

\section{RESEARCH METHODS}

This research is a normative legal research because it involves library materials or secondary data (Maria S.W. Sumardjono, 2014:17) as the research materials. Secondary data are the data already available (Maria S.W. Sumardjono, 2014:16) or obtained from library materials (Soerjono Soekanto, 1986: 51). The study uses both primary legal materials that include legislation in the field of notarial and the Criminal 
Code and secondary legal materials that include books discussing the Notary Honorary Council and the grounds of impunity (strafuitsluitingsgronden). Because the research is a normative legal research, the data collection technique used is documentary study with written materials ((Maria S.W. Sumardjono, 2014:25) as the data collection tool to be analyzed qualitatively using content analysis.

\section{DISCUSSION AND RESEARCH RESULT}

In carrying out his position in making a notarial deed, the notary has the obligation of professional secrecy, namely the obligation to conceal the contents of the deed and the information obtained in the notarial deed, unless ordered by the law that the notary is not required to keep confidential and provides necessary information related to the deed. The obligations are regulated in several articles of Law Number 30 of 2004 jo. Law Number 2 of 2014 as follows:

Article 4 paragraph (2) of the Law Number 30 of 2004 states that:

The oath as referred to in paragraph (1) shall read as follows:

"I pledge:

that I will be obedient and loyal to the Republic of Indonesia, Pancasila and the 1945 Constitution of the Republic of Indonesia, the Law on the position of notary and other Laws and regulations.

that I will carry out my office with trustworthy, honest, thorough, independent, and impartial.

that I will maintain my attitude, my conduct, and will perform my duties in accordance with the professional code of ethics, honor, dignity, and my responsibility as a notary.

that I will keep the contents of the deeds and the information obtained in the course of my office.

that I, to be appointed in this position, directly or indirectly, under any name or pretext, never and will not give or promise anything to anyone". 
Article 16 paragraph (1) letter $\mathrm{f}$ of Law Number 2 of 2014 states that:

To keep every information about the deed and all the information obtained for the deed making in accordance with the official oath, unless the Law specifies otherwise.

Article 54 paragraph (1) Law Number 2 of 2014 states that:

A notary may only grant, display, or notify the contents of the deed, the Grosse deed, the official duplicate copy of the deed or extrLaw of the deed to the person directly associated with the deed, heir, or person obtaining the rights, unless otherwise provided by Law.

The obligation of professional secrecy can be used with limitations when the notary is summoned for questioning by any agency seeking to ask a statement from the notary relating to a deed that has been or ever made by or in the presence of the notary (Habib Adjie, 2008: 89). The provision concerning the obligation to conceal everything dealing with deeds and other documents is to protect the interests of all parties related to the deed (see Elucidation of Article 16 paragraph (1) letter $\mathrm{f}$ of the Law Number 2 of 2014). To the breach of such obligations, the UUJN determines that the notary may be subject to verbal warning sanctions, written warning sanctions, temporary dismissal, dismissal with respect, or disrespectful dismissal (see Article 85 of the Law Number 30 of 2004). In addition, the Criminal Code also determines that the breach of such confidential can be threatened with a criminal Law as stipulated in Article 322 paragraph (1) of the Criminal Code which states "any person who with deliberate intent reveals a secret that he by reason of either his present or earlier office or profession is obliged to keep secret shall be punished with a maximum imprisonment of nine months or a maximum fine of six hundred rupiahs" (Moeljatno, 2011:117).

On the other hand, based on Law Number 2 of 2014 which now applies as a positive law, if the notary is involved in a criminal justice process, the Notary Honorary Council has an important role in giving consent as written in Article 66 paragraph (1) stating: 
For the purposes of the judicial process, the investigator, the public prosecutor, or the judge with the consent of the Notary Honorary Council is authorized to:

a. take a copy of minuta deed and/or documents attached to minute deed or notarial protocol in the notary's archives; and

$b$. invoke notary to be present in the examination relating to the deed of which he has made or the notarial protocol which is in the notary's archieves.

The provisions concerning the Notary Honorary Council are further stipulated in the Regulation of the Minister of Justice and Human Rights Number 7 of 2016 on the Notary Honorary Council. Based on the regulation a quo, the Notary Honorary Council is divided into Central Notary Honorary Council and Regional Notary Honorary Council (see Article 2 paragraph (1) the Regulation of the Minister of Justice and Human Rights Number 7 of 2016). The Regional Notary Honorary Council has the tasks:

a. to examine the petition filed by the investigator, prosecutor, and judge; and

b. to grant consent or rejection of a request for consent of the invitation to the notary to be present in the investigation, prosecution, and judicial proceedings (see Article 18 paragraph (1) the Regulation of the Minister of Justice and Human Rights Number 7 of 2016).

and has the authority, namely:

The authority of the Regional Notary Honorary Council based on the decision of the meeting which includes:

a. the examination of the notary that requests an consent to the Regional Notary Honorary Council of by investigators, prosecutors or judges;

b. the consent or rejection of the request for consent of taking the copy of minuta deed and/or documents attached to the minuta deed or notarial protocol in the notary archives; and

c. the consent or rejection of the request for consent of an invitation to notary the to be present in the investigation, prosecution and judicial proceeding related to the notarial deed or protocol in the notary 
archives (see Article 20 the Regulation of the Minister of Justice and Human Rights Number 7 of 2016).

Furthermore, in carrying out their duties and authorities, the Regional Notary Honorary Council consent the request of the investigator, public prosecutor or judge, the notary shall:

a. provide copies of the deed and/or documents necessary to the investigator, public prosecutor or judge; and

b. submit the copies of minuta deed and/or documents as referred to in document a with an official submission report signed by the notary and the investigator, public prosecutor or judge witnessed by 2 (two) witnesses (see Article 25 paragraph (3) the Regulation of the Minister of Justice and Human Rights Number 7 of 2016).

In the context of criminal law, the notary giving a copy of the deed and/or documents attached to the minuta deed or notarial protocol in the notary archives for the purpose of the investigator, the public prosecutor or the judge has committed a criminal Law of revelation of secrets as stipulated in Article 322 paragraph (1) of Criminal Code. However, the notary is not necessarily criminally liable. Discussed about criminal liability, means discussed about a person committing a criminal Law, in which in this case the notary as a criminal offender revelation of secrets as stipulated in Article 322 paragraph (1) of the Criminal Code. The Criminal Law separates the charLawer of the Laws that are criminalized and the character of the person performing it. Fletcher in Hiariej, completely states:

"We distinguish between characteristics of the act (wrongful, criminal) and characteristics of the actor (insane, infant). Indeed, the Model Penal Code builds on this distinction by defining insanity as a state of non responbility involving, in part, the absence of "substantial capacity to appreciate the wrongfulness of the criminal Law. This definition would not be coherent unless the isssue of responbility were separable from the issues of wrongfulness; if non-responsible acts were not wrongful, it would not make sense to say that insane actor did not appreciate the wrongfulness of his act" (Eddy O. S. Hiariej, 2016:153-154). 
According to Hiariej, in other words, a person who commits a criminal act is not necessarily criminally liable, depending on whether the criminal responsibility of the person can be sought for or not. Conversely, a person who is sentenced because of a crime must have committed a criminal Law and it is responsible. The most important element of criminal liability is fault (Eddy O. S. Hiariej, 2016:153-154). One element of the fault itself is the absence of grounds of impunity (strafuitsluitingsgronden) (Eddy O. S. Hiariej, 2016:163).

According to Hamdan (M. Hamdan, 2014:38-39, 86, 99, and 111112) and Hamzah (Andi Hamzah, 2017:140 and 167), the grounds of impunity viewed from the perspective of its source, is divided into two groups namely the grounds of impunity regulated by the law and unwritten. They also state that this can still be subdivided into a general grounds of impunity and a special grounds of impunity based on the science or doctrine of criminal laws (compare with Eddy O. S. Hiariej, 2016:254 and 288). The general grounds of impunity is the reason applicable to all criminal Law, while the special grounds of impunity is the reason applicable to certain criminal act (Andi Hamzah, 2017:140 and 167; M. Hamdan, 2014:38-39, 86, 99, and 111-112; Sudarto, 1990:138).

Additionally, the grounds of impunity according to the science or doctrine of criminal law is distinguished into fait justification (rechtsvaardigingsgronden) and the fait $d$ 'excuse (schulduitsluitingsgronden) (Andi Hamzah, 2017:140 and 167; Bambang Poernomo, 1981:193; Eddy O. S. Hiariej, 2016:253; M. Hamdan, 2014:29 and 39); Sudarto, 1990:139; J. Remmelink, 2014:244). The distinction between fait justification and the fait d 'excuse is derived from a German scholar named von Liszt and a French scholar named Mariauel (Andi Hamzah, 2017: 142). To this distinction, Fletcher in Hiariej comprehensively states:

"Claims of justification concede that definition of the offense is satisfied, but challenge whether the act is wrongful; claim of excuse concede the act 
is wrongful, but seek to avoid the attribution of the act to the actor. A justification speaks to the rightness of the act; an execuse, to whether the actor is accountable for a concededly wrongful act" (Eddy O. S. Hiariej, 2016:251).

In line with Fletcher, it is Sudarto who argues that fait justification abolish the unlawfullness of the crime. Hence, even though the act has fulfilled the formulation of a criminal act in the law, but if the conduct is not against the law, there will be no punishment. Whereas the fait $d$ 'excuse concerns the perpetrator's private, in the sense that this person cannot be censured (according to law). In other words, the offender is innocent or irresponsible, even if the action is unlawful. Thus, there are grounds of impunity that eliminate the offender fault so that there will be no punishment (Sudarto, 1990:139).

According to Poernomo (Bambang Poernomo, 1981:193) and Hamdan (M. Hamdan, 2014:33), the grounds of impunity can also be viewed from the elements of a crime that are the subjective and the objective elements. The subjective element is the element from within the person himself. Since this concern is from within the person of the perpetrator, the fait $d$ 'excuse is the grounds of impunity as the subjective element (subjective strafuitsluitingsgronden). The objective element is the element from outside the perpetrator's personality. In this case, the unlawfullness of the offender's act is abolished. Since the concern is from outside the perpetrator's personality, the fait justification is the grounds of impunity as the objective element (objective strafuitsluitingsgronden).

According to the Author, FIRSTLY, the Notary Honorary Council consent as previously described relates to the general grounds of impunity regulated by the law in enacting the execution of a statutory provision (wettelijk voorschrift). Article 50 Criminal Code regulates, "not punishable shall be the person who commits an act for the execution of a statutory provision" (Moeljatno, 2011:24). According to Poernomo, the grounds of impunity in Article 50 Criminal Code is the easiest way of thinking, because it is proper for anyone who by the law is given the duty to carry it 
out, there will be no punishment from another law, otherwise, no one would dare to enact laws that frequently contain strict prohibitions or orders. His conduct is not unlawful, so the act is justified for the fait justification (Bambang Poernomo, 1981:201). This is in accordance with the principle in Roman law stating that "juris enim executio non habet injuriam (execution of the law causes no injury) (J. Remmelink, 2014:305).

Initially, the "statutory provision" referred to the a quo article that is merely a law in the formal sense, in this case, the regulations made by the House of Representative and the President. Further, the "statutory provision" are broadly defined or from the material view defined as all binding general rules. This is based on the arrest of Hoge Raad 26 June 1899, W. 7307 and the arrest of Hoge Raad 30 November 1914, NJ 1915, 282, W. 9747 (Andi Hamzah, 2017:158). Thus, the Notary Honorary Council consent which requires the notary to provide a copy of the deed and/or the documents attached to minuta deed or notarial protocol in the notarial archives for the purpose of the investigator, the prosecutor or the judge as regulated in Article 66 paragraph (1) Act Number 2 of 2014 jo. Article 25 paragraph (3) of the Regulation of the Minister of Justice and Human Rights Number 7 of 2016 meets the parameters of "statutory provision" in Article 50 Criminal Code. This is because even though Article 25 Regulation of the Minister of Justice and Human Rights Number 7 of 2016 cannot be regarded as a law formaly, but can be regarded as a law materialy as has been recognized in the development of "statutory provision" according to the arrest-arrest Hoge Raad.

According to Schaffmeister, Keijzer, and Sutorius in Hiariej, the principle used in carrying out the "statutory provision" is subsidarity and proportionality. The principle of subsidarity in relation to the perpetrator's actions is to enforce the law and require the perpetrator to do so. Whereas the principle of proportionality is that the perpetrator is only justified if in the conflict between two legal obligations, the greater is preferred (Eddy 
O. S. Hiariej, 2016:279). This principle of proportionality requires a balance between the objectives to be achieved by means of the implementation (J. Remmelink, 2014:307). Another thing to consider in running the provisions of the law according to Fletcher in Hiariej is the character of the perpetrator whether the perpetrator always performing duties in good faith or not (Eddy O. S. Hiariej, 2016:279).

In relation to the principle of subsidiarity, Article 66 paragraph (1) Act Number 2 of 2014 jo. Article 25 paragraph (3) of the Regulation of the Minister of Justice and Human Rights Number 7 of 2016 strictly and explicitly requires the notary to provide the copies of the deed and/or documents attached to the minuta deed or notarial protocol in the notarial arcives for the purpose of the investigator, public prosecutor or judge. Subsequently, in relation to the principle of proportionality, the preferred legal obligation is the obligation to grant the copies of minuta deed and/or the documents attached to the minuta deed or notarial protocol in the notarial archives for the purposes of the investigator, public prosecutor or judge considering this relating to the criminal justice process. Certaintly, not only the way in which the implementation should be done in a good faith, but also the objectives to be achieved in carrying out the provisions of the law must refer to the parameters in Article 26 Regulation of the Minister of Justice and Human Rights Number 7 of 2016 stating that:

The withdrawal of minuta deed and or notary protocol in the notarial archives as referred to in Article number 25 shall be made in the case of:

a. allegations of criminal offenses relating to the minuta deed and/or the documents attached to minuta deed or notarial protocol in the notarial archives

b. the claim rights have not failed under the provisions of expiration in the laws and regulations of criminal law;

c. a denial of the signature of one or more parties;

d. any suspicion of reduction or addition to the minuta deed; or 
e. the notary allegedly made a postponement of the date (antidatum) (see Article 26 the Regulation of the Minister of Justice and Human Rights Number 7 of 2016).

SECOND, the Notary Honorary Council consent as set forth above is related to the special unwritten grounds of impunity in the form of permission or allowance (toestemming). The presence or absence of consent (the victim) have been playing an important role in the criminal law. It frequently means that because there is a consent, an act which in himself is against the law will be considered justified or lose its unlawfullness. Regarding this matter, Remmelink refers to the adagium volenti iniuria or nulla iniuria est, quae in voluntem fiat (against whom it gives a onsent, the action it approves does not raise an injustice against him) (J. Remmelink, 2014:324). In other words, permission or allowance may constitute the grounds of impunity, in this case the fait justification, if the acts committed have the consent of the person to be harmed from the act, that is, there is concent of victim (Eddy O. S. Hiariej, 2016:283-284).

Various theories have been proposed to further elaborate this fait justification. At least in this era we can refer to the important principle stating that the goverment is obliged to give the widest possible freedom to the people, but that freedom must be harmonized with the necessity of protecting the freedom of others and the importance (including the material) of other important laws. This implies that such consent can only concern the legal material within the scope of the authority of the consent giver (J. Remmelink, 2014:324). In the context of a notary involved in the criminal justice process in relation to the deed he makes, Article 66 paragraph (1) of the Law Number 2 of 2014 states that "for the benefit of the judicial process, investigator, prosecutor, or judge with the consent the Notary Honorary Council [...]" (see Article 66 paragraph (1) Law Number 2 of 2014). Thus, the consent of victim - the client who request the deed to make by the notary is represented by the Notary Honorary Council. 
According to Hiariej, the permission or consent as justification excuse is based on at least 4 conditions, namely:

1. The licensor does not give consent because of a guile;

2. The licensor is not in an oversight;

3. The licensor is not under pressure when giving a consent;

4. The substance of the problem which is given permission does not conflict with decency (Eddy O. S. Hiariej, 2016:284).

Thus, if the Notary Honorary Council in granting the consent is free from a deceit, an oversight, a pressure, and not contradictory to morality, the consent given by the Notary Honorary Council is a fait justification for the notary.

Furthermore, according to Remmelink. considering certain administrative interests, the presence or absence of a consent should be linked to formal compliance (J. Remmelink, 2014:324). In the context of the Notary Honorary Council consent, the formal requirement is contained in Article 66 paragraph (2) Law Number 2 of 2014 stating "the taking of the copy of minuta deed or documents as intended in paragraph (1) letter a, a submission report shall be made". Furthermore, it is regulated in Article 23 Regulation of the Minister of Justice and Human Rights Number 7 of 2016 which states:

(1) The request for consent of the withdrawal of minuta deed or notarial protocol and invitation for the notary by the investigator, public prosecutor or judge to be present in the examination related to notarial deed or notarial protocol in notarial archives is proposed by the concerned regional Notary Honorary Council.

(2) The application as referred to in paragraph (1) shall be submitted in writing in the Indonesian language and the copies shall be submitted to the Notary concerned.

(3) The application referred to in paragraph (2) shall contain at least:

a. The name of the notary; 
b. The office address of the notary

c. The number of the deeds and/or documents attached to a minuta deed or notarial protocol in the notarial archives; and

d. There is allegation of the addition or reduction of minuta deed.

(4) The Chairman of the Notary Honorary Council shall give an answer of consent or rejection of the application as referred to in paragraph (1) within a maximum period of 30 (thirty) working days from the receipt date of the application.

(5) If the time period referred to in paragraph (4) is exceeded, it shall be deemed that the Regional Notary Honorary Council receive the consent request.

and Article 24 states that:

(1) In conducting the examination, the examining board has the authority to call the notary on the basis of the request from the investigator, the public prosecutor or the judge.

(2) The summon to the notary as referred to in paragraph (1) shall be conducted through a document signed by the regional Notary Honorary Council.

(3) In urgent circumstances the summon may be invoked by facsimile and or electronic mail immediately followed by a summon document.

(4) The summon shall be made within 5 (five) days prior to the examination.

(5) Notary must be present to meet the appeals of the panel of examiners and may not be represented.

(6) In the event that the notary is absent after being summoned legally in 2 (two) consecutive times, the panel of examiners may decide on the request of the investigator or the judge. 


\section{E. CLOSING}

\section{E.1. CONCLUSION}

Based on the discussion, it can be deduced that in the context of criminal law, basically a notary who provides a copy of the deed and/or documents attached to the minuta deed or notarial protocol in the notarial archives for the purpose of the investigator, the public prosecutor or the judge has committed a criminal act of revelation of secrets as stipulated in Article number 322 paragraph (1) of the Criminal Code. However, the notary is not necessarily criminally liable considering the consent of the Notary Honorary Council as the grounds of impunity. Subsequently, the Notary Honorary Council consent not only relates to the general grounds of impunity regulated by the law in enacting the execution of a statutory provision (wettelijk voorschrift) as regulated in Article 50 Criminal Code, but also relates to special unwritten grounds of impunity in the form of permission or allowance (toestemming).

\section{E.2. SUGGESTION}

The Notary concerned in the criminal proceedings should not be afraid of the criminal penalties contained in Article 322 paragraph (1) Criminal Code in giving the copies of minuta deed and/or documents attached to minuta deed or notarial protocol in the notarial archives for the purpose of the investigator, the public prosecutor, or the judge as long as it has been consented by the Notary Honorary Council.

\section{BIBLIOGRAPHY:}

\section{Books:}

Adjie, Habib, 2008, Hukum Notaris Indonesia (Tafsir Tematik Terhadap UU No. 30 Tahun 2004 tentang Jabatan Notaris) (Legal Notary of Indonesia: Thematic Interpretation Against Law Number 30 of 2004 on The Notary), Bandung: PT Refika Aditama

Adjie, Habib, 2013, Sanksi Perdata dan Administratif Terhadap Notaris Sebagai Pejabat Publik, Cetakan Ketiga (Civil and Administratrive Sanctions Against Noatries as Public Officials), Bandung: Refika Aditama 
Hamdan, M, 2014, Alasan Penghapus Pidana Teori dan Studi Kasus, Cetakan Kedua (Causes of Crime Removal Theory and Case Study), Bandung: Refika Aditama

Hamzah, Andi, 2017, Hukum Pidana Indonesia (Indonesian Criminal Law), Jakarta: Sinar Grafika

H.S., Salim, 2016, Teknik Pembuatan Akta Satu (Konsep Teoretis, Kewenangan Notaris, Bentuk dan Minuta Akta), Edisi Pertama, Cetakan Kedua (Technique of Making Deed One: Theoretical Concepts, Notary Authority, Form and Minuta Deed), Jakarta: Rajawali Press

Moeljatno, 2011, KUHP Kitab Undang-Undang Hukum Pidana Cetakan Kedua Puluh Sembilan (Criminal Code), Jakarta: PT Bumi Aksara

Mulyoto, 2010, Kriminalisasi Notaris Dalam Pembuatan Akta Perseroan Terbatas (PT), Edisi Revisi (Criminalization of Notary in The Establishment of Deed of Limited Liability Company), Yogyakarta: Cakrawala Media

Hiariej, Eddy O.S, 2016, Prinsip-prinsip Hukum Pidana Edisi Revisi (Principles of Criminal Law), Yogyakarta:. Cahaya Atma Pustaka

Poernomo, Bambang, 1981, Asas-asas Hukum Pidana, Cetakan Keempat (Principles of Criminal Law). Yogyakarta: Ghalia Indonesia

Remmelink, J, 2014, Pengantar Hukum Pidana Material 1 Inleiding tot de Studie van het Nederlandse Strafrecht, diterjemahkan oleh Tristam P. Moeliono. Yogyakarta: Maharsa Publishing

Soekanto, Soerjono, 1986, Pengantar Penelitian Hukum Cetakan Ketiga (Introduction to Legal Research), Jakarta: UI-Press

Subekti, R., R. Tjitrosudibio, 2014, Kitab Undang-Undang Hukum Perdata (Burgerlijk Wetboek), Cetakan Keempat Puluh Satu, Jakarta: PT Balai Pustaka (Persero)

Sudarto, 1990, Hukum Pidana I, Cetakan Kedua (Criminal Law), Semarang: Yayasan Sudarto

Sumardjono, Maria S.W, 2014, Bahan Kuliah Metodologi Penelitian Ilmu Hukum (Lecture Material of Legal Research Methodology), Yogyakarta: Universitas Gadjah Mada

\section{Regulations:}

Law Number 30 of 2004 on Notary Public Official (State Gazette of the Republic of Indonesia Number 117 of 2004, Supplement to State Gazette of the Republic of Indonesia Number 4432).

Law Number 2 of 2014 on Amendment to Law Number 30 of 2004 on Notary Public Official (State Gazette of the Republic of Indonesia Number 3 of 2014, Supplement to State Gazette of the Republic of Indonesia Number 5491).

Constitutional Court Decision Number 49/PUU-X/2012.

Constitutional Court Decission Number 72/PUU-XI/2014. 
Regulation of the Minister of Justice and Human Rights Number 7 of 2016 on the Notary Honorary Council (Official Gazette of the Republic of Indonesia Number 180 Year 2016). 